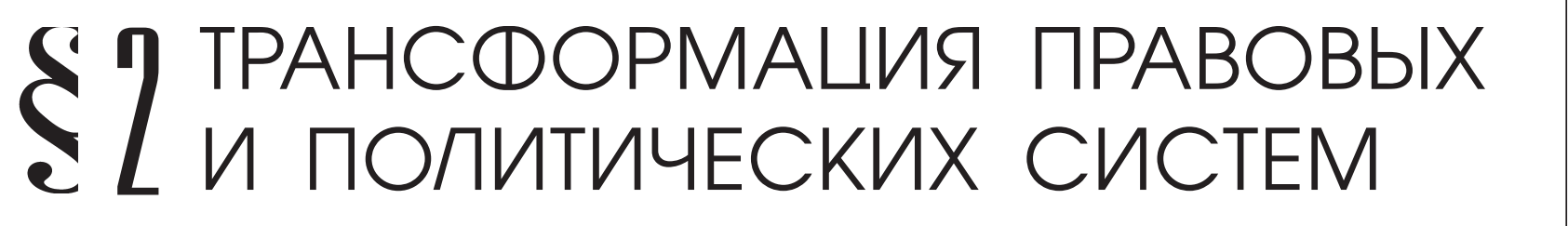

К.М. Беликова

\section{ТЕНДЕНЦИЯ К УНИФИКАЦИИ ЧАСТНОПРАВОВОГО РЕГУЛИРОВАНИЯ В СТРАНАХ ЛАТИНСКОЙ АМЕРИКИ HA ПРИМЕРE ESBOÇO DO CÓDIGO CIVIL 1856-1865 гr., ГК 1916 г. И ГК 2002 г. БРАЗИЛИИ}

\begin{abstract}
Аннотация: Частноправовые кодификации, будучи своего рода хранилищами национальной правовой традиции, вмещают в себя такие основополагающие правовые понятия, как «лицо», «обязательство», «договор», «гражданско-правовая ответственность» и др. Содержательное наполнение этих понятий изменчиво и объективно обусловлено. В связи с этим в настоящее статье автор исследует векторы развития бразильской гражданской кодификации на примере Esboço do Código civil 1856-1865 г2., ГК 1916 г. и ГК 2002 г. Бразилии с точки зрения отражений в ней тендениии к унификации частноправового ре-гулирования. Процесс поиска оптимальных путей систематизации частного права также присущ отечественной правовой системе: принятьй 19 лет назад ГК РФ в последнее время кардинально пересматривается. Поэтому снабжение участников работы над таким пересмотром дополнительными аргумен-тами из-за рубежа в пользу того или иного решения представляется автору целесообразным, своевременным и практически значимым.
\end{abstract}

Ключевые слова: Юриспруденция, Латинская, Америка, Бразилия, унификация, частноправового, регулирования, Esboço do Código civil , ГК 1916 г., ГК 2002 г.

есмотря на проявляющиеся время от времени тенденции, свидетельствующие о некоторых симптомах кризиса кодификации, государство не торопится отказываться от существующих частноправовых кодексов как таковых. Несмотря на то, что роль ГК, скажем, уже не столь значительна по сравнению с той, которую он играл раньше в большинстве государств, его политико-культурная ценность как хранилища национальной правовой традиции, и как следствие первичного элемента комплексного механизма, определяющего национальную идентичность государства, еще далеко не утрачена. ${ }^{1}$ Поэтому идея кодификации хоть и в несколько ином ракурсе, с иными акцентами, не утрачивает актуальности и по сей день, приобретая лишь иные формы: зарубежные правоведы говорят о таком явлении как «рекодификациия».

\footnotetext{
${ }^{1}$ Mengoni L. L'Europa dei codici o un codice per l'Europa? Centro di studi e ricerche di diritto comparato e straniero (ed.). Saggi, conferenze e seminari del Centro di studi e ricerche del diritto comparato e straniero, dirigido por M.J. Bonell, n. 7, Università di Roma "La Sapienza". Roma. 1992. URL: http://www.cisg.law.pace.edu/cisg/ biblio/mengoni.html (дата обращения: 13.11.2011).
}

Р. Кабрийяк ${ }^{2}$ определяет рекодификаичию как процесс и наиболее примечательный в сфере законодательства последних десятилетий феномен, появление которого трудно оспаривать, что позволяет говорить о наступлении нового этапа в проводимой, в том числе в странах Латинской Америки, кодификационной деятельности. По мнению Р. Кабрийяка, «рекодификация» принимает различные формы, - она может производиться в виде систематизации путем инкорпорации или консолидации ("recodificacióncompilación", reforma total) в порядке всеобъемлющей реформы, либо путем частичного (прогрессивного) реформирования (модификации - "recodificación-modificación", reforma parcial). В наших предыдущих работах мы уже касались этого вопроса, ${ }^{3}$ поскольку процесс «рекодифи-

\footnotetext{
${ }^{2}$ Cabrillac R. Recodifier, RTDC 2001-4-833. Цит. по: Rivera J.C. La recodificación. Un estudio de derecho comparado. URL: http://www. rivera.com.ar/publications/LaRecodificacion.pdf (дата обращения: 31.07.10)

${ }^{3}$ Беликова К.М. Договорное право стран БРИКС: опыт Бразилии в свете новой парадигмы построения частноправового регулирования. // Актуальные проблемы правоведения. - 2012. - № 2-3 (34-35). - С. 80-88; Она же. Кодификация в странах Латинской Америки: тенденция к унификации частноправового регулирова-
} 
Трансформация правовых и политических систем

кации» в настоящее время характерен и для Российской Федерации: принятый 19 лет назад ГК РФ в последнее время кардинально пересматривается. ${ }^{4}$ И, следовательно, исследование проблем, связанных с кодификацией в странах Латинской Америки представляется практически значимым с точки зрения снабжения российских правоведов - законодателей, практических деятелей и научных сотрудников - дополнительными теоретическими и практическими наработками зарубежных правоведов. Предметом рассмотрения в настоящей статье станут идеи, предпосылки и результаты рекодификации бразильской гражданской кодификации с точки зрения ретроспективы и современности на примере ГК Бразилии 2002 г., ${ }^{5}$ вступившего в силу 11 января 2003 г.

Этот кодекс провозглашает в качестве основополагающей идеи унификацию частноправового - гражданского и торгового - регулирования по образцу, скажем Гражданского кодекса Италии 1942 г.

Предвестником идеи унификации обязательственноправового регулирования в латиноамериканских странах считают бразильца А.Т. Фрейтаса. ${ }^{6}$ В его Esboço do Código civil, - одной из трех «оригинальных» латиноамериканских кодификаций, ${ }^{7}$ составленной им в 1856-1865 гг., были

ния (на примере проекта гражданского кодекса Аргентины 1998 г.). // Современное право. - 2012. - № 9. - С. 144-150; Она же. «Рекодификация» - вектор развития гражданского права (на примере проектов поправок к гражданскому и торговому кодексам Перу 1984 и 1902 гг.). // Вестник Российского университета дружбы народов. Серия «Юридические науки». - 2011. - № 4. - С. 110-116; Она же. Правовое регулирование торгового оборота и кодификация частного права в странах Латинской Америки. Монография / К.М. Беликова. - М.: Юстицинформ - 2010. - С. 102-150 (480 с.); Она же. Сравнительно-правовой обзор кодификации гражданского законодательства в Латинской Америке. // Сравнительное право. Частноправовое регулирование имущественного оборота в разносистемных правопорядках. / под ред. В.В. Безбаха, В.П. Серегина, Т.П. Данько. - М.: ГОУ ВПО «РЭА им. Г.В. Плеханова», 2009. С. 29-76 (452 c.).

${ }^{4}$ Проекты изменений, которые предлагается внести в разделы I, II, III и VI Гражданского кодекса Российской Федерации см., например, по адресу http://www.arbitr.ru/press-centr/news/31505.html и http://www.arbitr.ru/press-centr/news/31726.html (дата обращения: 02.02.11) - oф.c. ВАС РФ.

${ }^{5}$ Código civil do República Brasil (2002). (Novo Código Civil) Lei no 10.406, de 10.1.2002. Lei Ordinária. // DOFC PUB 11/01/2002, 000001, 1, Diário Oficial da União. URL: http://www.planalto.gov.br/ccivil_03/ LEIS/2002/L10406.htm (дата обращения: 31.07.10)

${ }^{6}$ Подробнее об А.Т. Фрейтасе см. Беликова К.M. Развитие научной мысли в персоналиях: политико-правовой аспект. - Саарбрюккен (Германия): LAP LAMBERT Academic Publishing GmbH \& Co. KG. - 2011. - C. 48-51 (104 c.) URL: https://www.lap-publishing.com/ catalog/details/store/gb/book/978-3-8473-0950-5/ Развитие-научноймысли-в-персоналиях: (дата обращения: 31.01.2012)

${ }^{7}$ Подобнее об «оригинальных» кодификациях Латинской Америки см. Беликова К.М. Правовое регулирование торгового оборота и кодификация частного права в странах Латинской Америки. закреплены положения, касающиеся торговых сделок, содержавшиеся в тот момент в Торговом кодексе 1850 г.

Он высказал и аргументировал представление о том, что одновременное действие гражданского и торгового кодексов (дихотомия частноправового регулирования) ничем не обоснованно и является следствием инертности законодателя. ${ }^{8}$ Выступая в Правительстве с обоснованием разработанного им Esboço, он настаивал на необходимости объединить положения Гражданского и Торгового кодексов с тем, чтобы устранить дублирование гражданских законов. ${ }^{9}$

В числе иных представлений А.Т. Фрейтаса, отраженных в Esboçо, можно назвать следующие: необходимость защиты человеческой личности с момента зачатия - начала юридического существования; отмена рабства ввиду того, что все человеческие существа являются лицами (persona) по той простой причине, что они принадлежат к виду людей; приверженность идеям римского права; отмена гражданской смерти и ограничения в гражданских правах и др. ${ }^{10}$

Оригинальность работе А.Т. Фрейтаса придает и тот факт, что он выдвинул совершенно новое и необычное по тем временам предложение, нашедшее отражение в подготовленном им проекте: снабдить изложение общим актом, в который включить общие положения об источниках права и порядке их применения. ${ }^{11}$ Однако эта идея не была воспринята бразильским законодательством (не был принят и сам проект). Такое построение кодексов, предусматривающее наличие общей части, и в практике европейских стран оказалось воплощенным только в конце столетия. ${ }^{12}$

Уже последующая кодификация - ГК Бразилии 1916 г., ${ }^{13}$ вступившая в силу 1 января 1917 г., отразила тенденщию

Монография / К.М. Беликова. - М.: Юстицинформ - 2010. - С. 36-63 (480 c.).

${ }^{8}$ Frontini P.S. "Unificação do Direito Privado: mais de um século de polêmica (ou a réplica dos fatos contra os doutores)", in Revista do Advogado, Associação dos Advogados de São Paulo, pág. 88; Karam, Munir. Teixeira de Freitas e o processo de codificação do direito civil brasileiro. // Revista de Direito Civil: imobiliário, agrário e empresarial, São Paulo, 1984. V. 8, n. 29, p. 95-112.

${ }^{9}$ Gumieri Valério M.A. Ainda sobre a unificação do direito privado no Brasil. 01.2002. URL: http://jus2.uol.com. br/doutrina/texto. asp?id=2802 (дата обращения: 31.07 .10 )

${ }^{10}$ Rabinovich-Berkman Ricardo D. 19 de agosto - día de la integración jurídica latinoamericana. URL: http://www.revistapersona.com.ar/ Persona67/67Freitas.htm (дата обращения: 31.07.10)

${ }^{11}$ Cм.: David R. Sources of Law. // International Encyclopedia of Comparative Law: V. 2. Ch.3. P.61.

${ }^{12} \mathrm{~B}$ частности в Германии, хотя и в более ограниченной сфере: только в рамках гражданской кодификации общая часть (Allgemeiner Teil) была включена в Гражданское уложение 1896 г.

${ }^{13}$ CM. Lei No 3.071 , de $1^{\circ}$ de Janeiro de 1916. (Lei Ordinária) Código Civil dos Estados Unidos do Brasil. // DOFC PUB 05/01/1916, 000133, 1, Diário Oficial da União). URL: http://www.planalto.gov.br/CCIVIL/ LEIS/L3071.htm (дата обращения: 31.07.10) 


\section{Право и политика $2(158) \cdot 2013$}

к упразднению дуализма частноправового регулирования в Бразилии. ${ }^{14}$ Проект этого кодекса был разработан в 1899 г. К. Бевилака (Clovis Bevilaqua), завершив череду неудачных попыток выработки ГК, предпринятых Н. де Араухо (Nabuco de Araujo), Ф. дош Сантошом (Felício dos Santos) и К.Родригесом (Coelho Rodrigues). Своим строением он первым из кодексов латиноамериканских стран отразил влияние новаторской для того времени идеи - был снабжен общей частью - и состоял, таким образом, из двух частей - Общей и Особенной.

В Общей части, разбитой на 3 книги, помещались общие положения о лицах (физических и юридических), о гражданском местожительстве, о различных классах имущества, юридических фактах, давности и т. д. Особенная часть состояла из 4-х книг: I - О семейном праве; II - О вещном праве; III - Об обязательственном праве; IV - О наследственном праве (всего 1807 статей).

Следуя общей для латиноамериканских стран традиции, ГК Бразилии предпослан вводный закон, в котором аналогично вводным титулам иных кодексов (в частности, Чили и Аргентины) сосредоточены нормы о вступлении законов в силу, порядке их применения, исполнении иностранных законов и т.д.

По общему правилу гражданская дееспособность физических лиц наступала с 21 года. Абсолютно недееспособными признавались несовершеннолетние до 16 лет, глухонемые, которые неспособны выражать свою волю, и лица, объявленные судом безвестно отсутствующими.

ГК 1916 г. подразделяет юридические лица на лица публичного (внешнего или внутреннего) и частного права. К юридическим лицам внешнего публичного права относятся иностранные государства и иные лица, деятельность которых регулируется международным публичным правом. К юридическим лицам внутреннего публичного права ГК относил федерацию, ее штаты и федеральный округ, муниципальные округа. Юридическими лицами частного права признавались гражданские, благотворительные, научные и литературные общества, общественно-полезные союзы и фонды, торговые товарищества, вносившиеся в генеральный реестр юридических лиц (ст. 13-16, 18).

В семейных отношениях, продолжая традиции латиноамериканских гражданских кодексов, жена находилась под властью мужа, она не могла от своего имени заниматься коммерцией и представлять себя в суде. Ее гражданская дееспособность была относительной (relativa) как у мужчин, не достигших 21 года. Только в 1962 г. в ст. 233 ГК были внесены изменения, которые смягчили неравенство супругов. Кодекс признавал действительным только гражданский брак, заключенный с соблюдением предусмотренных требований и зарегистрированный в го-

${ }^{14}$ Martins F. Curso de direito comercial. Rio de Janeiro: Forense, 1991. P. 36. сударственных органах. Расторжение брака путем развода допускалось через предварительную процедуру сепарации по указанным в законе основаниям или при фактическом раздельном проживании в течение более двух лет.

ГК 1916 г. в ст. 524 устанавливал, что: «Закон обеспечивает собственнику право пользования, владения и распоряжения своими вещами и право истребовать их из власти тех, кто ими владеет». ${ }^{15}$ Имущество рассматривалось под традиционным углом зрения, подвергаясь делению на движимое и недвижимое. ${ }^{16}$ Недвижимое имущество подлежало обязательной регистрации, которая презюмировала наличие права собственности у лица, указанного в поземельной книге в качестве собственника.

В ГК Бразилии 1916 г. более отчетливо по сравнению с другими латиноамериканскими кодексами проявилась тенденция к выделению в системе закрепляемых гражданскими кодексами таких норм о собственности, которые специально посвящались земле как объекту вещных прав - появилась отдельная статья, указывающая на объем права собственности на землю: «Право собственности на земельный участок распространяется как на пространство, находящееся над поверхностью, так и на недра, расположенные под ним» (ст. 526). Одновременно бразильский ГК впервые закрепил иные, относящиеся к земле, специальные нормы в ряде статей - об экспроприации недвижимости в целях общественной полезности или необходимости (ст. 590; ст. 1150), о сельскохозяйственном залоге (ст. 783), об издольщине (ст. 1410, 1412-1413, 1415). ${ }^{17}$ Эти ограничения следует рассматривать сквозь призму социальной функции собственности в целом, и недвижимости, в частности. ${ }^{18}$

Представляется, что исходя из имманентно присущих недвижимой собственности характеристик правомочий

\footnotetext{
${ }^{15}$ Подробнее о правомочиях собственника см.: Rodrigues Silvio. Direito Civil vol 5 - Direitos das Coisas. Editora Saraiva, São Paulo. $28^{\mathrm{a}}$ edição - 2009. P. 128 (448 pág.).

${ }^{16}$ Бразильскому законодательству известны и определенные отступления от такого деления: согласно положениям Воздушного кодекса, утвержденного Законом № 32 от 18 ноября 1966 г., самолеты и по ныне не относятся ни к движимому, ни к недвижимому имуществу, а именуются «вещами, подлежащими регистрации» (ст. 10).

${ }^{17}$ Гражданское и семейное право развивающихся стран: Гражданские кодексы стран Латинской Америки. / отв. ред. В. В. Безбах. - М.: Изд-во УДН, 1988. - С. 56, 57.

${ }^{18}$ Fabio Luiz Gomes. Direito de propriedade - uma extensão do direito da personalidade. // Revista "Direito Vivo" URL: http://www.estacio. br/publicacoes/direitovivo/pdf/Artigo_Fabio-Revista_Eletronica.pdf (дата обращения: 31.07.10).

О социальной функции собственности в латиноамериканских кодификациях см. подробнее Беликова К.М. Социально-ориентированные императивы в латиноамериканских гражданских кодексах. // Нравственные императивы в праве. - 2011. - № 3. -C. 39-46. URL: http://moscou-ecole.ru/lib/nrav_imp/nravstvennye imperativy_v_prave_2011_n_3.pdf (дата обраще-ния: 16.07.2012)
} 
собственника - абсолютного (свобода распоряжения) и исключительного (владения и пользования), а также непрерывного (переходящего наследнику после смерти собственника) характера, - ограничения также можно рассматривать в этих трех направлениях. Абсолютный характер правомочий собственника лимитируется ограничениями (restrição); исключительный характер - сервитутами (servidão); непрерывный характер - экспроприацией.

Исторически в Бразилии тенденция к унификации частноправового регулирования была возрождена в 1941 г. с момента формирования Комиссии в составе Ф.Асеведо (Philadelpho Azevedo), О.Нонато (Orozimbo Nonato) и Х.Гимараеса (Hahnemann Guimarães) для пересмотра положений действующего ГК 1916 г.

Такой пересмотр был произведен посредством принятия законодательства, отражающего современные тенденции в сфере частноправового регулирования, в частности, стремление пресекать проявления крайнего индивидуализма и нивелировать двойственный характер принципов, отраженных в действующих на тот момент гражданском и торговом кодексах на основе унификации предписаний обоих сводов. ${ }^{19}$ Этот проект, однако, не был успешен.

В 1961 г. была создана Комиссия по изучению законодательства, призванная реформировать частное право в Бразилии в составе таких известных юристов как опять-таки О.Нонато и К.М да Сильва Перейра (Саiо Mário da Silva Pereira), которые взялись за создание проектов Обязательственного кодекса (Código de Obrigações) и Гражданского кодекса. ${ }^{20}$ Результаты работы этой Комиссии также оказались неудовлетворительными.

В 1972 г. появился Проект ГК, опубликованный 7 августа в Официальном бюллетене (Diário Oficial) и явившийся результатом работы юристов M.Реале (Miguel Reale), Х.К. Морейра Альвеса (José Carlos Moreira Alves), А. де Арруда Альвима (Agostinho de Arruda Alvim) и др. В их задачу входило снабдить страну современным гражданским и торговым законодательством, учитывающим самобытное развитие отечественной правовой мысли, исторические основы формирования бразильского общества с опорой на принцип социализации, в том числе социальной функции права.

Мотивацией необходимости унифицировать частноправовое регулирование послужили следующие обстоятельства и факторы. Разработчики отмечали, что торговые обычаи и обыкновения распространяются на всех без исключения лиц, включая граждан, кроме случаев, когда законодатель закрепляет иное. Деятельность бирж, банков, заключение договоров купли-продажи и

${ }^{19}$ Cм.: Requião R. Curso de direito comercial. $7^{\mathrm{a}}$ ed. São Paulo: Saraiva, 1976, v. 01. Р. 19. Цит. по: Gumieri Valério M.А. Op. cit.

${ }^{20}$ Cruz A.Á. Compêndio de direito comercial. São Paulo: Revista dos Tribunais, 1994. P. 12. Ibid. кредитного, открытия текущего счета и др. исторически обусловленная обращением к специальному субъекту, в настоящее время приобрела всеобщий характер. ${ }^{21}$ Ведь при обсуждении проектов гражданских кодексов редко находит подтверждение необходимость разграничивать сделки в зависимости от их предпринимательской, лукративной цели, - полагали они, - поскольку применительно к правовому результату заключаемых сделок она не имеет значимых последствий. Представляется, однако, несправедливым подчинять потребителей, заведомо более слабую сторону отношений в сфере торгового оборота, обычаям и обыкновениям, действующим между предпринимателями. Ставя этот вопрос, бразильские правоведы ${ }^{22}$ рассматривают его в привычном отечественным правоведам формате. ${ }^{23}$ Согласно ему торговое право прошло в своем развитии несколько этапов, обусловленных социально-политическим и экономическим развитием государств: от сословно-купеческого права до национальных корпоративных актов эпохи монархизма, от субъективных критериев этих актов - к объективизированным актам буржуазного общества - торговым кодексам. ${ }^{24}$

По мере развития экономики торговое право постепенно стало отражать смешанный подход, при котором объективный принцип дополняется субъективным: принимает за основу характеристику субъекта соответствующих отношений с описанием совершаемых им актов торговли (например, в ГТУ 1897 г.). ${ }^{25}$ Таким образом, существование рядом с гражданским правом торгового может быть объяснено только историческими традициями. По этой причине Проект ГК Бразилии 1975 г. устранял дуализм частноправового регулирования.

Вместе с тем, бразильские правоведы, критикующие идеи унификации, говорят о том, что нормы sui generis должны существовать, ведь как не крути, а из Проекта ГК 1975 г. были исключены положения, регламентирующие деятельность акционерных обществ, что, однако, вызвало негодование другой части ученых и практиков ввиду того, что такое привилегированное положение ничем не обосно-

\footnotetext{
${ }^{21}$ Borges J.E. Curso de direito comercial terrestre. $2^{\mathrm{a}}$ ed. Rio de Janeiro: Forense, 1964. P. 132 y ss.

${ }^{22}$ См., например, Jaeger A. Jr. O novo código civil brasileiro e a reorganização de empresa. // Boletín Latinoamericano de Competencia. № 15. Octubre 2002. P. 52-76. URL: http://ec.europa.eu/competition/ publications/blc/boletin_15_1.pdf (дата обращения: 08.01.2013); Martins F. Op. cit. P. 51, 52 .

${ }^{23}$ См., например, Шершеневич Г.Ф. Курс торгового права. Т. 1: Введение. Торговые деятели. - М.: «Статут», 2003. - С. 54-71.

${ }^{24}$ Pont M.B. La empresa, la unificación del derecho de obligaciónes y el derecho mercantil. Madrid. Tecnos, 1965. P. 28-44.

${ }^{25}$ Pont M.B. Op. cit. Р. 71; Гражданское и торговое право зарубежных государств: Учебник. / отв. ред. Е.А. Васильев, А.С. Комаров. - 4-е изд., перераб. и доп. В 2-х т. - Т. I. - М.: Междунар. отношения, 2004. - С. 164, 165.
} 


\section{Право и политика $2(158) \cdot 2013$}

вано - ведь такие общества суть торговые товарищества и только. Такое же, специальное, регулирование предполагалось в отношении ценных бумаг (акций, облигаций) и иных долговых документов (векселей и т.д.).

Как бы то ни было, к необходимости модернизации гражданского законодательства Бразилии привело, - отмечает один из разработчиков кодекса М.Реале, ${ }^{26}$ превращение в XX в. Бразилии из аграрной страны в промышленно развитую. «Первоначально, - говорит он, - основной идеей в ходе реформирования положений ГК 1916 г. было сохранение по возможности большей части его положений в неизменном виде, однако, очень скоро Комиссии по реформе стала очевидна невозможность достижения поставленной цели в виду несовместимости многих его положений с реалиями современной жизни и завоеваниями науки частного права. Этот кодекс, таким образом, иллюстрирует подход, основывающийся на представлении о необходимости проведения всеобъемлющей, а не частичной реформы.» ${ }^{27}$

Структура нового ГК Бразилии 2002 г повторяет структуру ГК 1916 г. Как и предыдущий ГК состоит из Общей (Parte geral) и Особенной части (Parte especial). Общая часть включает 3 книги: Книга 1. О лицах; Книга 2. О вещах; Книга 3. О юридических фактах. Особенная часть состоит из пяти книг: Книга 1. Об обязательственном праве; Книга 2. О вещах; Книга 3. О вещном праве; Книга 4. О семейном праве; Книга 5. О наследственном праве.

Своеобразием подхода бразильского законодателя является то обстоятельство, что унификация частноправового регулирования видится сквозь призму закрепляемой на уровне ГК концепции «предпринимательской деятельности» (atividade empresarial). По сути, речь идет о своеобразном совмещении двух рассмотренных выше подходов к трактовке предмета торгового права. Так, Книга II Особенной части ГК Бразилии 2002 г. «Право предприятия» (Direito de Empresa) отходит от традиционной закрепленной Торговым кодексом 1850 г. системы, базировавшейся на фигуре коммерсанта и профессиональном занятии торговлей (уже упоминавшаяся teoria dos atos de comércio), оперируя категорией «предприниматель» (empresário) и «предпринимательская деятельность» (atividade empresarial - teoria da empresa - Титул I Книги II Особенной части). Ключевой фигурой становится фигура предпринимателя, осуществляющего на профессиональной основе экономическую деятельность, организованную для производства и продажи на рынках товаров и услуг. ${ }^{28}$

${ }^{26}$ См., например, Reale M. O novo código civil brasileiro, Rev. de Derecho Comparado, nº 4, pág. 185. Цит. по: Rivera J.C. Op. cit.

${ }^{27}$ Ibid.

${ }^{28}$ Machado D.C. O Novo Código Civil Brasileiro e a Teoria da Empresa. URL: http://www.mt.trf1.gov.br/judice/jud11/O_Novo_Código_Civi_Brasileiro_e_a_Teoria_da_Empresa.htm (дата обращения:
Предпринимательской (empresarial) считается любая экономическая деятельность, направленная на извлечение прибыли (atividade lucrativa), осуществляемая на профессиональной основе и организованная с целью производства или введения в оборот товаров и услуг (ст. 966 ГК). Исключение составляет интеллектуальная деятельность научного характера, а также литературная или художественная.

Согласно ст. 40 ГК 2002 г. юридические лица подразделяются на юридические лица публичного права, внутреннего или внешнего, и частного права (as pessoas jurídicas são de direito público, interno ou externo, e de direito privado). К юридическим лицам внутреннего публичного права относятся: 1) объединения (союзы); 2) штаты, федеральный округ, территории (territórios); 3) муниципалитеты; 4) автаркии (autarquias); 5) иные учреждения публичного характера, создаваемые законом (ст. 41). К юридическим лицам внешнего публичного права относятся иностранные государства и иные лица, деятельность которых регулируется международным публичным правом (ст. 42). К юридическим лицам частного права относятся: 1) ассоциации (associações); 2) товарищества (общества - sociedades); 3) учреждения (fundações); 4) религиозные организации; 5) политические партии (ст. 44). ${ }^{29}$

При этом новый ГК также устранил подразделение товариществ на товарищества, действующие согласно предписаниям гражданского права и торговые товарищества. Торговые товарищества (sociedades comerciais) получили в ГК 2002 г. наименование предпринимательских (sociedades empresárias - ст. 982, 983 и др.), а категория торгового фонда (fundo de comércio) уступила место понятию «торговое обзаведение» (estabelecimento)..$^{30}$ Теперь товарищества подразделяются исходя из того, в каком реестре они зарегистрированы, - предпринимательские (sociedades empresárias) подлежат регистрации в Государственном реестре торговых товариществ (Registro Público de Empresas Mercantis Советом по торговле); непредпринимательские (sociedades não-empresárias) - в Гражданском реестре юридических лиц (Registro Civil das Pessoas Jurídicas - Реестродержателем правоустанавливающих документов). Регламентация деятельности акционерных обществ производится на осно-

31.07.10); Bulgarelli W. Direito Comercial. 15 $5^{\mathrm{a}}$ Edição. São Paulo: Atlas, 2000. P 19.

${ }^{29}$ ГК Бразилии 1916 г. к юридическим лицам внутреннего публичного права относил федерация, ее штаты и федеральный округ, муниципальные округа. Юридическими лицами частного права признавались гражданские, благотворительные, научные и литературные общества, общественно полезные союзы и фонды, торговые товарищества, вносившиеся в генеральный реестр юридических лиц (ст. 13-16, 18).

${ }^{30}$ Reale, Miguel. Exposição de Motivos do Projeto de Código Civil. Subsecretaria de Edições Técnicas do Senado Federal, v. 5, t. 2, Brasília, 1989. P. 17. 
вании положений Закона № 6.404 от 15 декабря 1976 г. об акционерных обществах, ${ }^{31}$ тогда как деятельность обществ с ограниченной ответственностью регламентируется положениями ГК (подробнее см. ниже).

Торговые сделки, находившие ранее закрепление в Торговом кодексе, не будучи регламентированы специальным законодательством, регулируются положениями раздела об обязательствах ГК 2002 г. (Direito das Obrigações), либо попадают в сферу действия законодательства о защите прав потребителей и предписаний трудового или административного права. Сохраняют действие также отдельные законы, регламентирующие заключение и исполнение некоторых видов торговых сделок, например, купли-продажи. Хотя Книга 1 Особенной части ГК называется «Об обязательственных правах», в кодексе отсутствует определение обязательства. Ст. 233, открывающая эту часть, говорит о нескольких разновидностях обязательств: обязательствах по предоставлению определенной и неопределенной вещи (obrigações de dar coisa certa и obrigações de dar coisa incerta) и обязательствах позитивного и негативного свойства - сделать что-либо (obrigações fazer) и не делать что-либо (obrigações nao fazer).

ГК 2002 г. распространил приничипы добросовестности и солидаризма (socialidade), на договорные отношения, а также подтвердил приверженность солидаристских представлений применительно к отношениям по поводу собственности, в частности, применительно к приобретению и прекращению права собственности в силу приобретательной давности. Кроме того, тексту ГК была придана бо́льшая ясность и простота.

Примером солидаристского императива может служить провозглашение соичиальной функции договора. Так, согласно положениям ст. 421 ГК свобода заключать договор осуществляется в пределах социальной функции договора. В этой связи применительно к договору присоединения ст. 423 гласит: «в случае, когда в договоре присоединения содержатся противоречивые или двусмысленные условия, их надлежит толковать наиболее благоприятным для присоединяющейся стороны образом». ${ }^{32}$ Также как в свое время было объективно обусловлено нормативное закрепление идеи социальной функции

\footnotetext{
${ }^{31}$ Lei das Sociedades por Ações - "Sociedades Anônimas" No. 6.404 de15 de dezembro de 1976. // DOFS PUB 17/12/1976 0000011 Diário Oficial da União - Supl. URL: https:// www.planalto.gov.br/ccivil_03/ LEIS/L6404consol.htm\#art300 (дата обращения: 31.07.10)

32 Подробнее о социальной функции договора в ГК Бразилии 2003 г. см.: Moreno Talavera G. A Função Social do Contrato no Novo Código Civil. // Revista do Conselho da Justiça Federal, n. ${ }^{\circ}$ 19, 2002. URL: http://www.estig.ipbeja.pt/ ac direito/fsocial.pdf (дата обращения: 31.07.10); Reale M. Função Social do Contrato, 2003. URL: http://www.miguelreale.com.br/artigos/funsoccont.htm (дата обращения: 31.07.10)
}

собственности, удовлетворению объективной потребности в защите более слабой стороны правоотношения содействует соответствующая ориентация императивных норм законодательства.

Применительно к владению, в русле следования общепринятому в настоящее время подходу к упразднению различий правовых последствий, вытекающих из характера владения - добросовестного и недобросовестного - ГК 2002 г., исходя из соииальной природы владения вещью, сократил срок приобретательной давности. Так, согласно положениям ст. 1238 ГК 2002 г. действовавший ранее в отношении недвижимого имущества (propriedade imóvel) 15-летний срок приобретательной давности сокращен до 10 лет независимо от того, является ли владение добросовестным или нет. Для того, чтобы стать собственником, владелец должен в течение этого 10-летнего срока фактически осуществлять действия, дающие третьим лицам снования полагать, что он считает рассматриваемую недвижимость местом своего жительства (располагает на ней свое жилище) или осуществлять на ней работы (оказывать услуги) производительного характера.

Одновременно, согласно ст. 1239 ГК 2002 г. непрерывный 5-летний срок считается достаточным для того, чтобы владелец земельного участка, располагающегося в сельской местности (área em zona rural), размером более 50 га, приобрел право собственности на него, при соблюдении следующих условий: 1) он не является собственником недвижимости, расположенной в сельской местности или в черте города; 2) превратил за этот период участок, которым владеет, своими усилиями или усилиями своей семьи в плодоносящий и 3) считает его местом своего жительства (располагает на нем свое жилище).

В этом смысле также согласно положениям ст. 1240 тот, кто непрерывно в течение 5 лет владеет как своим собственным городским земельным участком (área urbana) размером 250 кв. м и использует его в качестве места жительства своего или своей семьи, при условии, что никто не противопоставляет ему свое право владения, приобретает право собственности на него, если не является к этому моменту собственником иной недвижимости. Принцип солидаризма проявляется также в положениях ст. 1242, согласно которым право собственности на недвижимое имущество приобретает лицо, которое в течение 10 лет владеет им в бесспорном порядке (incontestavelmente), непрерывно и добросовестно. ГК Бразилии 2002 г. систематизирует вещные права, выделяя, право собственности и иные вещные права, в том числе суперфиций; сервитут; узуфрукт; пользование (uso); право проживания в чужом доме; залог; ипотеку; антихрез и обещание произвести куплю-продажу недвижимости (promessa de compra e venda); уступка вещного права пользования и уступка специального права поль- 


\section{Право и политика $2(158) \cdot 2013$}

зования с целью проживания (concessão de uso especial para fins de moradia). ${ }^{33}$ После регистрации договора об обещании произвести куплю-продажу недвижимости в Реестре недвижимости, покупатель приобретает вещное право покупки недвижимости, выступающей предметом договора (ст. 1417). Вещные права на недвижимость и обеспечивающие их акты для целей настоящего ГК признаются недвижимым имуществом (п. 1 ст. 80).

Право собственности предполагается полным (plena) и исключительным (exclusiva) пока не установлено иное (ст. 1231). Ст. 1228 ГК определяет его следующим образом: «Собственник вправе владеть, пользоваться и распоряжаться вещью (coisa) и вправе истребовать ее у того, кто незаконно владеет ею или является ее держателем». ${ }^{34}$

Из приведенного определения видно, что ГК 2002 г. проводит различие между владением (possua) и держанием (detenta), что свидетельствует о закреплении в нем субъективной теории владения. Согласно ст. 1196 владение рассматривается как фактическое отношение лица к вещи, позволяющее ему в полном или неполном объеме реализовывать какие-либо правомочия, принадлежащие по своей природе собственнику. Оно не включается в систему вещных прав, закрепленную ст. 1225 ГК.

ГК разграничивает непосредственное и опосредованное владение. Под непосредственным владением (posse direta) понимается владение вещью, которая находится под властью владельца. Опосредованным (posse indireta) является владение, при котором вещь находится в держании одного лица (detentor), а намерение владеть принадлежит другому лицу, которое и считается владельцем. Различается также добросовестное и недобросовестное владение (ст. 1198).

Касаясь вопроса дееспособности ГК 2002 г. гласит: «Всякое лицо способно приобретать права и обязанности (deveres) в гражданском порядке» ${ }^{35}$ (ст. 1 Книги 1 Общей части). Предписаниями ст. 2 предусматривает, что гражданская личность человека начинается с рождения живым, одновременно закон признает и защищает права еще не родившегося ребенка с момента зачатия.

Согласно положениям ст. 1511 Книги 4 Особенной части, регулирующей семейные правоотношения, в основе брака лежит совместное проживание (comunhão plena de vida), базирующееся на равенстве прав и обязанностей супругов. Имущественный режим супруги свободно избирают по своему усмотрению. И для мужчин, и для женщин возраст вступления в брак признается равным

${ }^{33}$ ГК 1916 г. предусматривал и иные вещные права - эмфитевзис и ренту, установленную в отношении недвижимости (ст. 674).

${ }^{34}$ ГК 1916 г. в ст. 524 предусматривал право собственника осуществлять правомочия пользования, владения и распоряжения в отношении его имущества (seus bens).

${ }^{35}$ ГК 1916 г. оперировал термином «obrigações» - обязательства.
16 годам. В числе условий действительности брака указывается необходимость получения разрешения обоих родителей или их законных представителей и согласия лиц, вступающих в брак.

К наиболее важным положениям наследственного права относится свобода завещательных распоряжений, распространяющаяся, однако, только на половину наследства, если имеются обязательные наследники (ст. 1789), которые должны получить не менее половины доли, которая бы причиталась им при наследовании по закону (ст. 1846). К числу последних ГК 2002 г. относит родственников по нисходящей и восходящей линиям и пережившего супруга.

Эти и другие положения ГК позволяют исследователям говорить о смещении акцента с подхода, в рамках которого приоритетной защитой пользовались собственник, кредитор, хозяин, на - защиту прав личности (раздел II книги первой), в русле конституционных ${ }^{36}$ и иных законодательных положений, ${ }^{37}$ семьи, потребите-

${ }^{36}$ Так, статья 5 Конституции Бразилии 1988 г. (Constituição Federal de 1988. Brasil. Texto consolidado até a Emenda Constituciónal n ${ }^{\circ} 66$ de 13 de julho de 2010. URL: http://www.senado.gov.br/legislacao/ const/ - дата обращения: 31.07.10) гарантирует неприкосновенность частной жизни, уважение чести и достоинства личности, а также дает право на возмещение морального и материального вреда, в том случае, если эти гарантии нарушены. Неприкосновенным также считается жилище, - никто не может войти в него без разрешения жильца (не считая тех случаев, когда есть подозрение, что в жилище произошло бедствие, совершается преступление, или если необходимо оказать кому-то экстренную помощь); закон позволяет вторжение в жилище в дневное время с разрешения суда. Конституция Бразилии запрещает перлюстрацию почтовых сообщений, телеграмм и прочих видов связи. Прослушивание телефонных разговоров возможно исключительно при расследовании уголовных преступлений, только с разрешения суда и при соблюдении условий и правил, оговоренных законодательством. Каждый имеет доступ к информации, при этом гарантируется неразглашение ее источника в тех случаях, когда это необходимо для профессиональной деятельности. Кроме того, в Бразилии существует и особое право - так называемое Habeas Data, гарантирующее каждому гражданину а) доступ ко всей напрямую относящейся к его личности информации, содержащейся в базах данных государственных органов или общественных организаций и б) возможность исправить данные в административном порядке или по решению суда, если гражданин не хочет воспользоваться конфиденциальной процедурой.

37 Указанные выше конституционные гарантии защиты приватности и информации были позднее подкреплены дополнительными законодательными актами. Так, например, в 1990 г. был принят Закон о защите потребителей (Lei No 8.078 del 11/09/90 - Código de Defesa do Consumidor. (DOU 12/09/1990, Suplemento). URL: http:// www.consumidorbrasil.com.br/consumidorbrasil/textos/legislacao/cdc. $\mathrm{htm})$, в котором, помимо прочего, говорится и о защите их персональных данных. По закону потребитель имеет право доступа к содержащейся в архивах, реестрах и базах данных информации о его/ее личности, а также имеет право знать, каким образом эти данные были получены. Информация о потребителях должна быть объективной, достоверной, изложенной понятным и простым 
лей, лиц с разного рода недостатками, что рассматривается в качестве существенного продвижения вперед по сравнению с ГК 1916 г. $^{38}$

Изложенное позволят сделать и некоторые другие общие выводы. «Оригинальный» Esboço А.Т. Фрейтаса закреплял ряд прогрессивных идей, направленных на искоренение представлений, несовместимых с провозглашенным в то время в Латинской Америке в качестве вектора развития либерализмом. Так, например, своевременно его предложение об отмене гражданской смерти, рабства и пр.

Применительно к ГК 1916 г., на наш взгляд, представляется возможным говорить о том, что этот кодекс является в полной мере национальным, обусловленным и выражающим социально-политические и экономические реалии Бразилии в рассматриваемый период. Поэтому, в частности, происходит своеобразное уравнивание мужчин и женщин в правах в семейных отношениях; отличительной особенностью кодекса 1916 г. является отход от концепции либерального индивидуализма и закрепление в них идей социальной функции собственности и солидаризма. В русле идей социальной функции собственности и солидарности абсолютный характер правомочий собственника лимитируется ограничениями (restrição); исключительный характер - сервитутами (servidão); непрерывный характер - экспроприацией и т.д.

«Новейший» унифицированный бразильский гражданский кодекс - ГК 2002 г., появившийся в результате полномасштабной реформы ГК 1916 г., отличается от ГК начала и середины XX в. тем, что его разработчики не претендуют на беспробельность и долговременность своего творения. Дело в том, что хотя он и совмещает в себе положения, направленные на регламентацию и актов общегражданских, и актов торговых, целью новейшей кодификации (и ГК Бразилии не единичный случай ${ }^{39}$ )

языком, а также не должна содержать умаляющих человеческое достоинство фактов более чем пятилетней давности. Кроме того, потребители должны быть извещены в письменной форме об использовании их персональных данных (кроме тех случаев, когда это происходит по их желанию). Если потребитель обнаруживает неточность в касающейся его информации, он может потребовать исправления ошибки, что должно быть осуществлено сотрудниками базы данных или архива в течение 5 дней. Помимо этого, если потребитель расплатился с долгами, кредитные организации не должны распространять о нем какую-либо информацию, которая может помешать ему/ей при получении кредитов.

${ }^{38}$ Entrevista com o Professor Carlos Roberto Gonçalves. URL: http:// www.juspodivm.com.br/novo/concursos_entrevista_prof_carlos_roberto.asp (дата обращения: 31.10.07)

39 Так, например, во Франции действует «Кодекс по защите прав потребителей» (Code de la consommation), «Страховой кодекс» (Code des assurances), «Кодекс прав интеллектуальной собственности» (Code de la propriété intellectuelle) и др. URL: http://www. legifrance.com/initRechCodeArticle.do (дата обращения: 03.12.10) не является больше всесторонний охват положениями вводимых в действие кодексов всех существующих в настоящее время частноправовых институтов; современная кодификация относится к более узкому кругу общественных отношений по сравнению с кодексами частного права эпохи промышленного капитализма, регламентируя их больше на уровне отдельных институтов.

Положениями этого кодекса провозглашается равенство прав и обязанностей супругов; продолжается развитие в направлении уравновешивания принципа свободы завещательных распоряжений необходимостью предоставления заранее известному кругу лиц «обязательной доли».

Дальнейшее развитие получает принцип социальной функции права, находящий выражение в усилении публично-правовых начал в регулировании имущественных отношений. Еще отчетливее проявляется тенденция к законодательному ограничению договорной свободы с целью защиты более слабого участника договора, что, по мнению автора, иллюстрирует приверженность к дифференцированному регулированию однородных общественных отношений в зависимости от их субъектного состава, от которого бразильский законодатель стремится уйти, унифицируя соответствующие положения.

Вектор развития бразильской гражданской кодификации состоит во все большей социализации гражданского права путем:

- во-первых, внедрения императива, нацеленного на защиту слабой стороны договора, призванного дополнить принцип автономии воли,

- во-вторых, дальнейшей последовательной реализации императива, подтверждающего социальную природу собственности и владения путем ограничения интересов собственника имущества в пользу интересов общества, сокращения сроков приобретательной давности и пр.

\section{Библиография:}

1. Borges J.E. Curso de direito comercial terrestre. $2^{\mathrm{a}}$ ed. Rio de Janeiro: Forense, 1964.

2. Bulgarelli W. Direito Comercial. $15^{\mathrm{a}}$ Edição. São Paulo: Atlas, 2000.

3. Cabrillac R. Recodifier, RTDC 2001-4-833. Цит. по: Rivera J.C. La recodificación. Un estudio de derecho comparado. URL: http://www.rivera.com.ar/publications/ LaRecodificacion.pdf (дата обращения: 31.07.10)

4. Código civil do República Brasil (2002). (Novo Código Civil) Lei n ${ }^{\circ} 10.406$, de 10.1.2002. Lei Ordinária. // DOFC PUB 11/01/2002, 000001, 1, Diário Oficial da União. URL: http://www.planalto.gov.br/ccivil_03/LEIS/2002/ L10406.htm (дата обращения: 31.07.10) 


\section{Право и политика 2 (158) • 2013}

5. Código de Defesa do Consumidor - Lei $\mathrm{N}^{\circ} 8.078$ del 11/09/90. // DOU 12/09/1990, Suplemento. URL: http:// www.consumidorbrasil.com.br/consumidorbrasil/textos/ legislacao/cdc.htm (дата обращения: 08.01.2013)

6. Constituição Federal de 1988. Brasil. Texto consolidado até a Emenda Constituciónal n ${ }^{\circ} 66$ de 13 de julho de 2010. URL: http://www.senado.gov.br/legislacao/const/ - дата обращения: 31.07.10)

7. Cruz A.Á. Compêndio de direito comercial. São Paulo: Revista dos Tribunais, 1994. P. 12.

8. David R. Sources of Law. // International Encyclopedia of Comparative Law: V. 2. Ch.3. P.61.

9. Entrevista com o Professor Carlos Roberto Gonçalves. URL: http://www.juspodivm.com.br/novo/concursos_entrevista_prof_carlos_roberto.asp (дата обращения: 31.10.07)

10. Fabio Luiz Gomes. Direito de propriedade - uma extensão do direito da personalidade. // Revista "Direito Vivo" URL: http://www.estacio.br/publicacoes/direitovivo/pdf/ Artigo_Fabio-Revista_Eletronica.pdf(дата обращения: 31.07.10).

11. Frontini P.S. "Unificação do Direito Privado: mais de um século de polêmica (ou a réplica dos fatos contra os doutores)", in Revista do Advogado, Associação dos Advogados de São Paulo, pág. 88.

12. Gumieri Valério M.A. Ainda sobre a unificação do direito privado no Brasil. 01. 2002. URL: http://jus2.uol.com.br/ doutrina/texto.asp?id=2802 (дата обращения: 31.07 .10 )

13. Jaeger A. Jr. O novo código civil brasileiro e a reorganização de empresa. // Boletín Latinoamericano de Competencia. № 15. Octubre 2002. P. 52-76. URL: http://ec.europa.eu/competition/publications/blc/boletin_15_1.pdf (дата обращения: 08.01.2013)

14. Karam, Munir. Teixeira de Freitas e o processo de codificação do direito civil brasileiro. // Revista de Direito Civil: imobiliário, agrário e empresarial, São Paulo, 1984. V. 8, n. 29, p. 95-112.

15. Lei das Sociedades por Ações - "Sociedades Anônimas" No. 6.404 de15 de dezembro de 1976. // DOFS PUB 17/12/1976 0000011 Diário Oficial da União - Supl. URL: https:// www.planalto.gov.br/ccivil_03/LEIS/ L6404consol.htm\#art300 (дата обращения: 31.07.10)

16. Lei $\mathrm{N}^{\mathrm{o}} 3.071$, de $1^{\circ}$ de Janeiro de 1916. (Lei Ordinária) Código Civil dos Estados Unidos do Brasil. // DOFC PUB 05/01/1916, 000133, 1, Diário Oficial da União). URL: http://www.planalto.gov.br/CCIVIL/LEIS/L3071.htm (дата обращения: 31.07.10)

17. Machado D.C. O Novo Código Civil Brasileiro e a Teoria da Empresa. URL: http://www.mt.trf1.gov.br/judice/ jud11/O_Novo_Código_Civi_Brasileiro_e_a_Teoria_da Empresa.htm (дата обращения: 31.07.10)

18. Martins F. Curso de direito comercial. Rio de Janeiro: Forense, 1991.
19. Mengoni L. L'Europa dei codici o un codice per l'Europa? Centro di studi e ricerche di diritto comparato e straniero (ed.). Saggi, conferenze e seminari del Centro di studi e ricerche del diritto comparato e straniero, dirigido por M.J. Bonell, n. 7, Università di Roma "La Sapienza". Roma. 1992. URL: http://www.cisg.law.pace.edu/cisg/ biblio/mengoni.html (дата обращения: 13.11.2011).

20. Moreno Talavera G. A Função Social do Contrato no Novo Código Civil. // Revista do Conselho da Justiça Federal, n. ${ }^{\circ}$ 19, 2002. URL: http://www.estig.ipbeja.pt/ ac_direito/ fsocial.pdf (дата обращения: 31.07.10);

21. Pont M.B. La empresa, la unificación del derecho de obligaciónes y el derecho mercantil. Madrid. Tecnos, 1965.

22. Rabinovich-Berkman Ricardo D. 19 de agosto - día de la integración jurídica latinoamericana. URL: http://www. revistapersona.com.ar/Persona67/67Freitas.htm (дата обращения: 31.07.10)

23. Reale M. Função Social do Contrato, 2003. URL: http:// www.miguelreale.com.br/artigos/funsoccont.htm (дата обращения: 31.07.10)

24. Reale M. O novo código civil brasileiro, Rev. de Derecho Comparado, no 4 , pág. 185.

25. Reale, Miguel. Exposição de Motivos do Projeto de Código Civil. Subsecretaria de Edições Técnicas do Senado Federal, v. 5, t. 2, Brasília, 1989. P. 17.

26. Requião R. Curso de direito comercial. $7^{\mathrm{a}}$ ed. São Paulo: Saraiva, v. 01. 1976

27. Rodrigues Silvio. Direito Civil vol 5 - Direitos das Coisas. Editora Saraiva, São Paulo. 28ª edição - 2009. 448 pág.

28. Беликова К.М. «Рекодификация»-вектор развития гражданского права (на примере проектов поправок к гражданскому и торговому кодексам Перу 1984 и 1902 гг.). // Вестник Российского университета дружбы народов. Серия «Юридические науки». 2011. - № 4. - С. 110-116.

29. Беликова К.М. Договорное право стран БРИКС: опыт Бразилии в свете новой парадигмы построения частноправового регулирования. // Актуальные проблемы правоведения. - 2012. - № 2-3 (34-35). - С. 80-88.

30. Беликова К.М. Кодификация в странах Латинской Америки: тенденция к унификации частноправового регулирования (на примере проекта гражданского кодекса Аргентины 1998 г.). // Современное право. 2012. - № 9. - С. 144-150.

31. Беликова К.М. Правовое регулирование торгового оборота и кодификация частного права в странах Латинской Америки. Монография / К.М. Беликова. - М.: Юстицинформ - 2010. - 480 с.

32. Беликова К.М. Развитие научной мысли в персоналиях: политико-правовой аспект. - Саарбрюккен (Германия): LAP LAMBERT Academic Publishing GmbH \& Co. KG. - 2011. - 104 c. URL: https://www. 
lap-publishing.com/catalog/details/store/gb/book/9783-8473-0950-5/ Развитие-научной-мысли-в-персоналиях: (дата обращения: 31.01.2012)

33. Беликова К.М. Сравнительно-правовой обзор кодификации гражданского законодательства в Латинской Америке. // Сравнительное право. Частноправовое регулирование имущественного оборота в разносистемных правопорядках. / под ред. В.В. Безбаха, В.П. Серегина, Т.П. Данько. - М.: ГОУ ВПО «РЭА им. Г.В. Плеханова», 2009. - С. 29-76 (452 с.).

34. Гражданское и семейное право развивающихся стран: Гражданские кодексы стран Латинской Америки. / отв. ред. В. В. Безбах. - М.: Изд-во УДН, 1988.

35. Гражданское и торговое право зарубежных государств: Учебник. / отв. ред. Е.А. Васильев, А.С. Комаров. - 4-е изд., перераб. и доп. В 2-х т. Т. I. - М.: Междунар. отношения, 2004.

36. Шершеневич Г.Ф. Курс торгового права. Т. 1: Введение. Торговые деятели. - М.: «Статут», 2003.

\section{References (transliteration):}

1. Belikova K.M. «Rekodifikatsiya» - vektor razvitiya grazhdanskogo prava (na primere proektov po-pravok $\mathrm{k}$ grazhdanskomuitorgovomukodeksam Peru 1984i 1902 gg.). // Vestnik Rossiyskogo universiteta druzhby narodov. Seriya «Yuridicheskie nauki». - 2011. - № 4. - S. 110-116.

2. Belikova K.M. Dogovornoe pravo stran BRIKS: opyt Brazilii v svete novoy paradigmy postroe-niya chastnopravovogo regulirovaniya. // Aktual'nye problemy pravovedeniya. - 2012. - № 2-3 (34-35). - S. 80-88.
3. Belikova K.M. Kodifikatsiya v stranakh Latinskoy Ameriki: tendentsiya $\mathrm{k}$ unifikatsii chastnopravo-vogo regulirovaniya (na primere proekta grazhdanskogo kodeksa Argentiny 1998 g.). // Sovremennoe pravo. 2012. - № 9. - S. 144-150.

4. Belikova K.M. Pravovoe regulirovanie torgovogo oborota i kodifikatsiya chastnogo prava $\mathrm{v}$ stranakh Latinskoy Ameriki. Monografiya / K.M. Belikova. - M.: Yustitsinform - 2010. - $480 \mathrm{~s}$.

5. Belikova K.M. Razvitie nauchnoy mysli v personaliyakh: politiko-pravovoy aspekt. - Saarbryukken (Germaniya): LAP LAMBERT Academic Publishing GmbH \& Co. KG. - 2011. - 104 s. URL: https://www.lap-publishing. com/catalog/details/store/gb/book/978-3-8473-0950-5/ Razvitie-nauchnoy-mysli-v-personaliyakh: (data obrashcheniya: 31.01.2012)

6. Belikova K.M. Sravnitel'no-pravovoy obzor kodifikatsii grazhdanskogo zakonodatel'stva v La-tinskoy Amerike. // Sravnitel'noe pravo. Chastnopravovoe regulirovanie imushchestvennogo oborota $\mathrm{v}$ raznosistemnykh pravoporyadkakh. / pod red. V.V. Bezbakha, V.P. Seregina, T.P. Dan'ko. - M.: GOU VPO «REA im. G.V.Plekhanova», 2009. - S. 29-76 (452 s.).

7. Grazhdanskoe i semeynoe pravo razvivayushchikhsya stran: Grazhdan $\neg$ skie kodeksy stran Latinskoy Ame-riki. / otv. red. V. V. Bezbakh. - M.: Izd-vo UDN, 1988.

8. Grazhdanskoe i torgovoe pravo zarubezhnykh gosudarstv: Uchebnik. / otv. red. E.A. Vasil'ev, A.S. Ko-marov. 4-e izd., pererab. i dop. V 2-kh t. - T. I. - M.: Mezhdunar. otnosheniya, 2004.

9. Shershenevich G.F. Kurs torgovogo prava. T. 1: Vvedenie. Torgovye deyateli. - M.: «Statut», 2003. 